\title{
HUBUNGAN TINGKAT PENGETAHUAN IBU TENTANG DEMAM DENGAN PENANGANAN DEMAM PADA BAYI 0-12 BULAN DI DESA DATARAJAN WILAYAH KERJA PUSKESMAS NGARIP KABUPATEN TANGGAMUS TAHUN 2018
}

\author{
Ani Kristianingsih 1, Yona Desni Sagita 2 Imas Suryaningsih2 \\ Program DIV Kebidanan, STIKes Aisyah Pringsewu, Lampung, anikristianingsih539@gmail.com \\ Program DIV Kebidanan, STIKes Aisyah Pringsewu, Lampung, yonayori1207@gmail.com,

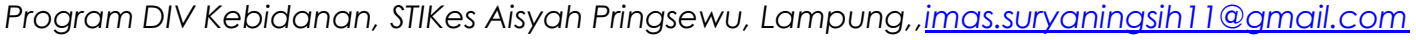

INFO ARTIKEL

Riwayat Artikel:

Diterima: 10-10-2018

Disetujui: 05-12-2018

\section{Kata Kunci: \\ Pengetahuan Ibu \\ Demam \\ Penanganan Demam}

\begin{abstract}
Abstrak: Demam adalah suatu tanda bahwa tubuh sedang melawan infeksi atau bakteri yang berada di dalam tubuh. Apabila demam tidak ditangani maka dapat mengakibatkan kerusakan rangkaian khususnya sistem saraf pusat dan otot, sehingga mengakibatkan kematian. Penanganan pertama demam dapat berupa terapi farmakologi dan terapi non farmakologi. Tujuan dari penelitian ini untuk mengetahui hubungan tingkat pengetahuan ibu tentang demam dengan penanganan demam pada bayi 0-12 bulan di Datarajan Wilayah Kerja Puskesmas Ngarip Kabupaten Tanggamus tahun 2018. Jenis penelitian yang digunakan dalam penelitian ini adalah kuantitatif. Rancangan penelitian yang digunakan adalah cross sectional. Waktu pelaksanaannya pada tanggal 11-13 Februari 2018 tempatnya di Desa Datarajan Wilayah Kerja Puskesmas Ngarip Kabupaten Tanggamus. Populasi yaitu ibu yang memiliki bayi $0-12$ bulan berjumlah 60 orang. Pengambilan sampel dengan menggunakan total population dengan jumlah 60 ibu. Hasil analisis menunjukan ada hubungan tingkat pengetahuan ibu tentang demam dengan penanganan demam dengan $\mathrm{P}$-value 0,000 (<0.05) dengan odds Ratio sebesar 25.375 (6.357-101.287). Diharapkan hasil penelitian ini dapat menambah pengetahuan bagi ibu dengan pengetahuan kurang baik. Ibu dapat mengikuti sosialisasi kesehatan. Sehingga ibu dapat melakukan penanganan demam yang baik didorong dengan adanya informasi kesehatan baik dari tenaga kesehatan ataupun orang tua dan saudara ibu dalam penanganan demam.
\end{abstract}

ABSTRAK

\begin{abstract}
Fever is a sign that the body is fighting an infection or bacteria that is in the body. If the fever is not treated it can cause damage to the circuit especially the central nervous system and muscle, resulting in death. The first treatment of fever may be pharmacological therapy and non pharmacological therapy. The purpose of this study to determine the relationship of knowledge level of mother about fever with fever handling in infants 0-12 months in Datarajan Working Area Health Center Ngarip Tanggamus in 2018. The type of research used in this study is quantitative. The research design used was cross sectional. Its implementation time on 11-13 February 2018 its place in Datarajan Working Area Health Center Ngarip Tanggamus. The population of mothers have a babies 0-12 months amounted to 60 people. Sampling using total population with amount of 60 mothers. The result of the analysis showed that there was a correlation between maternal knowledge level of fever and fever treatment with P-value $0.000(<0.05)$ with Ratio odds $25,375(6,357-101,287)$. It is expected that the results of this study can increase knowledge for mothers with less good knowledge. Mothers can follow health socialization. Then the mother can do a good fever handling driven by health information either from health workers or parents and mother sisters in the handling of fever.
\end{abstract}

\section{A. LATAR BELAKANG}

Demam adalah suatu tanda bahwa tubuh sedang melawan infeksi atau bakteri yang berada di dalam tubuh. Demam juga biasanya menjadi pertanda bahwa sistem imunitas anak berfungsi dengan baik (Nurdiansyah, 2011). Protokol Kaiser Permanente Appointment and Advice Call Center mendefinisikan demam yaitu temperatur rektal diatas $38^{\circ} \mathrm{C}$, aksila $37,5^{\circ} \mathrm{C}$ dan diatas $38,2^{\circ} \mathrm{C}$ dengan pengukuran membrane tympani. Sedangkan dikatakan demam tinggi apabila suhu tubuh $>41^{\circ} \mathrm{C}$ (Kania 2010).
Demam pada bayi dan balita terjadi ketika suhu tubuh diatas 38 derajat celsius (Arifianto, 2012). American Academy of Pediatrics (AAP) menyebutkan bahwa demam sering disebabkan oleh infeksi virus seperti batuk, flu, radang tenggorokan, common cold (selesma) dan diare (Depkes RI, 2000, Susanto, 2007).

Menurut Suryaningsih (2013), data terakhir yang diperoleh dari Survei Kesehatan Nasional (Susenas) 2010 tentang angka kesakitan bayi dan balita menunjukkan bahwa 49,1 \% bayi umur kurang dari 1 tahun (49,0 \% bayi laki-laki, 49,2 \% bayi perempuan), dan $54,8 \%$ balita umur $1-4$ tahun (55,7\% balita laki-laki, 
54,0 \% balita perempuan). Di antara anak umur o-4 tahun tersebut ditemukan prevalensi panas sebesar $33,4 \%$, batuk $28,7 \%$, batuk dan nafas cepat $17,0 \%$ dan diare $11,4 \%$.

Angka kesakitan bayi dan balita di Indonesia cukup tinggi dan terjadi peningkatan dari setiap tahunnya, yaitu pada tahun 2012 mencapai 47,7\% kesakitan pada bayi dan balita, dan cukup signifikan mengalami peningkatan pada tahun 2013 sebesar 71,4\%. Sebesar 95\% ibu bingung bila anaknya demam, alasan ibu karena demam pada bayi menyebabkan kejang (69\%), kerusakan otak (16\%), koma (14\%), gejala dari penyakit yang berat (11\%), bahkan demam bisa menyebabkan kematian (Fauzie, 2014).

Di kabupaten Tanggamus angka kesakitan bayi dan balita tahun 2015 adalah kelainan bawaan 3 (25\%), febris 2 (17\%), kecelakaan 2 (17\%),meningitis 2 (17\%), diare 1 (8\%), gizi buruk 1(8\%), demam berdarah 1 (8\%), dan leukemia 1 (8\%) (Dinkes,2015). Data Dinkes Kabupaten Tanggamus tahun 2016 mencatat angka kejadian demam tahun 2016 sebanyak 57 balita $(7,5 \%)$ dari jumlah balita sakit sebanyak 680 balita. Sedangkan data tahun 2017 tercatat kejadian demam sebanyak 52 balita $(6,6 \%)$ dari jumlah balita sakit sebanyak 784 balita (Dinkes Tanggamus, 2017).

Para ibu biasanya menyamakan tingginya demam dengan beratnya suatu penyakit yang menyerang bayinya. Demam yang mencapai $41^{\circ} \mathrm{C}$ disebut hipertermia. Ada kira-kira 0.05\% kejadian hipertermia pada bayi dan balita di Indonesia.

Apabila demam tidak ditangani maka dapat mengakibatkan kerusakan rangkaian khususnya sistem saraf pusat dan otot, sehingga mengakibatkan kematian. Demam yang mencapai suhu $41^{\circ} \mathrm{C}$ angka kematiannya mencapai $17 \%$, suhu $43^{\circ} \mathrm{C}$ akan koma dengan angka kematian $70 \%$, dan pada suhu $45.5^{\circ} \mathrm{C}$ akan meninggal dalam beberapa jam (Suryaningsih, 2013).

Sebagian besar kasus demam pada bayi di sebabkan oleh infeksi akut, yang dapat bersifat lokal atau sistemik. Penyebab yang lebih jarang meliputi penyakit kolagen vascular, neoplasma dan kelainan neurologis. Demam dengan penyebab yang tidak diketahui secara khas di tandai oleh demam selama dua minggu atau lebih tanpa tanda- tanda lokal atau diagnose spesifik, memerlukan perhatian pada pola, frekuensi dan tingginnya temperature sepanjang waktu. (Lisnawati,2013).

Penanganan pertama demam dapat berupa terapi farmakologi dan terapi non farmakologi. Terapi farmakologi yang digunakan biasanya adalah berupa memberikan obat penurun panas, sedangkan terapi non farmakologi yang dapat dilakukan yaitu mengenakan pakaian tipis, lebih sering minum, banyak istirahat, mandi dengan air hangat, serta memberi kompres (Saito, 2013). Tindakan kompres yang dapat dilakukan antara lain kompres hangat basah, kompres hangat kering dengan larutan obat antiseptik, kompres basah dingin dengan dengan air biasa dan kompres dingin kering dengan kirbat es atau kantung untuk mengkompres (Asmadi, 2008).

Masyarakat sering mengartikan demam dan diare sebagai sakit tifus. Dengan demikian orang tua akan melakukan pola pemberian makan ke arah diet tifus, yakni makan bubur. Demikian praktik yang salah terus berlangsung setiap bayi menderita demam. Kandungan kalori yang diterima rendah pada bubur beras menyebabkan status gizi anak menurun, sedangkan untuk melawan serangan infeksi, tubuh harus mempunyai persediaan zat gizi yang cukup. Demam menyebabkan pemecahan protein tubuh yang besar sehingga memerlukan masukan makanan sumber protein, kalori, vitamin, mineral yang ditemukan pada telur, susu, kacang, dan kacang hijau (Adiningsih, 2010).

Sejauh ini demam menimbulkan fobia tersendiri bagi banyak ibu. Hasil penelitian (Setyani,2014) memperlihatkan hampir $80 \%$ orang tua mempunyai fobia demam. Banyak ibu yang mengira bahwa bila tidak diobati, maka demam akan semakin tinggi. Karena konsep yang salah ini, banyak orang tua mengobati demam ringan yang sebetulnya tidak perlu diobati. Salah satu penatalaksanaan awal yang bisa dilakukan ibu dalam mengatasi demam yaitu mengompres dengan menggunakan air hangat dan memberikan obat penurun panas.

Berdasarkan Pra survey yang dilakukan pada tanggal 16 Desember 2017 di Puskesmas Ngarip didapatkan angka bayi dan balita sakit pada tahun 2017 sebanyak 784 bayi dan balita dengan kejadian demam di des, Datarajan (140 bayi) Ulu Semong (14 bayi), Muara 2 (12 bayi), Ngarip (12 bayi), Tanjung Ban (12 bayi), Gunung Sari (12 bayi), Rejosari (11 bayi), Petai Kayu (11 bayi), Sri Banten (10 bayi), Penantian (10 bayi), Suka Maju (10 bayi), Pagar Alam (10 bayi). Dari bulan Januari hingga November tahun 2017 angka kesakitan bayi dan balita yang mengalami demam paling banyak di dapatkan di desa Datarajan yaitu sebanyak 140 bayi. Di Datarajan terdapat dua posyandu, yang pertama yaitu posyandu Blok 1 terdapat 90 bayi dan balita, diantaranya 60 bayi usia 0-12 bulan terdiri dari 33 bayi perempuan dan 27 bayi laki-laki. Dan di posyandu Blok 2 terdapat 70 bayi dan balita, diantaranya 42 bayi berusia $0-12$ bulan terdiri dari 30 bayi perempuan dan 12 bayi laki-laki. Dari survey yang di dapatkan di posyandu blok 1 bahwa pengetahuan ibu tentang penanganan demam pada bayi kebanyakan ibu masih salah, seperti menggunakan jaket dan kaos kaki pada bayi yang mengalami demam, dan mengompres bayi yang demam dengan menggunakan air dingin atau alcohol. Selain itu pendidikan kesehatan tentang penanganan demam pada bayi juga belum pernah diajarkan. Padahal apabila demam tidak ditangani dengan tepat dapat mengakibatkan kejang demam, yang dapat bedampak pada kerusakan sistem syaraf pusat dan otot sehingga dapat mengakibatkan kematian. Dari survey yang di dapatkan di posyandu blok 2 bahwa pengetahuan dan penanganan demam pada bayi sudah 
baik, ibu mengetahui penanganan demam seperti mengompres bayinya dengan air hangat, menyusui bayi sesering mungkin dan memberikan obat penurun panas sesuai pemberian bidan apabila demam tidak kunjung menurun. Berdasarkan hal tersebut maka peneliti mengambil judul "Hubungan Tingkat Pengetahuan Ibu Tentang Demam Dengan Penanganan Demam Pada Bayi 0-12 Bulan di Desa Datarajan Wilayah Kerja Puskesmas Ngarip Kabupaten Tanggamus tahun 2018”.

\section{B. METODE PENELITIAN}

Jenis penelitian yang digunakan ini adalah kuantitatif, penelitian kuantitatif adalah metode yang digunakan untuk menyelidiki objek yang dapat diukur dengan angka-angka, sehingga gejala- gejala yang diteliti dapat diteliti/diukur dengan menggunakan skala-skala, indeks-indeks atau tabel-tabel yang kesemuanya lebih banyak menggunakan ilmu pasti (Notoatmodjo, 2010).

Penelitian ini menggunakan desain penelitian analitik, yaitu penelitian yang menyangkut pengujian hipotesis, yang mengandung uraian- uraian tetapi fokusnya terletak pada analisis hubungan antara variabel (Notoatmodjo, 2010). Desain penelitian yang digunakan adalah cross sectional yaitu suatu desain penelitian dengan cara pendekatan, observasi atau pengumpulan data pada satu waktu (poin time approach). Artinya setiap subjek penelitian hanya diobservasi sekali saja dan pengukuran dilakukan terhadap status karakter subjek pada saat penelitian (Arikunto, 2010).

Penelitian ini telah dilaksanakan pada tanggal 11 13 Februari 2018 di Posyandu Desa Datarajan Wilayah Kerja Puskesmas Ngarip Kabupaten Tanggamus tahun 2018.

Populasi yang diambil adalah seluruh ibu yang memiliki bayi usia 0-12 bulan di Datarajan Wilayah Kerja Puskesmas Ngarip Kabupaten Tanggamus tahun 2018 yaitu berjumlah 60 orang. Sampel dalam penelitian ini adalah ibu yang memiliki bayi usia 0-12 bulan berjumlah 60 orang dengan total sampling.

\section{HASIL DAN PEMBAHASAN}

a. Analisis Univariat

1) Distribusi frekuensi pengetahuan ibu di Desa Datarajan Wilayah Kerja Puskesmas Ngarip Kabupaten Tanggamus tahun 2018

TABEL 1

Distribusi frekuensi pengetahuan ibu di desa datarajan wilayah kerja puskesmas ngarip kabupaten tanggamus tahun 2018

\begin{tabular}{ccc}
\hline Pengetahuan & Frekuensi & Persen (\%) \\
\hline Baik & 35 & 58.3 \\
Kurang Baik & 25 & 41.7 \\
\hline Total & 60 & 100.0 \\
\hline
\end{tabular}

Dari tabel 1 dapat dijelaskan bahwa dari 60 responden didapatkan $35 \quad(58,3 \%)$ ibu dengan pengetahuan baik dan $25 \quad(41,7 \%)$ ibu dengan pengetahuan kurang baik. Dapat disimpulkan bahwa sebagian besar ibu dengan pengetahuan baik.

2) Distribusi frekuensi penanganan demam di Desa Datarajan Wilayah Kerja Puskesmas Ngarip Kabupaten Tanggamus tahun 2018

TABEL 2

Distribusi frekuensi penanganan demam di desa datarajan wilayah kerja puskesmas ngarip kabupaten tanggamus tahun 2019

\begin{tabular}{ccc}
\hline $\begin{array}{c}\text { Penanganan } \\
\text { Demam }\end{array}$ & Frekuensi & Persen (\%) \\
\hline Baik & 33 & 55.0 \\
Tidak Baik & 27 & 45.0 \\
\hline Total & 60 & 100.0 \\
\hline
\end{tabular}

Dari tabel 2 dapat dijelaskan bahwa dari 60 responden didapatkan hasil 33 (55\%) ibu melakukan penanganan demam baik dan 27 (45\%) ibu melakukan penanganan demam tidak baik. Dapat disimpulkan bahwa sebagian besar penanganan demam yang ibu lakukan adalah baik.

b. Analisis Bivariat

TABEL 3

Hubungan tingkat pengetahuan ibu tentang demam dengan penanganan demam pada bayi o-12 bulan di desa datarajan wilayah kerja puskesmas ngarip kabupaten tanggamus tahun 2018

\begin{tabular}{lcccccccc}
\hline $\begin{array}{c}\text { Penanganan } \\
\text { demam }\end{array}$ & Baik & Tidak baik & Total & P & $\begin{array}{c}\text { OR } \\
(95 \% \mathrm{CI})\end{array}$ \\
\hline Pengetahuan & F & $\%$ & F & $\%$ & F & $\%$ & & \\
Kurang baik & 21 & 84,0 & 4 & 16,0 & 25 & 100 & & \\
Baik & 6 & 17,1 & 29 & 82,9 & 35 & 100 & 0 & $(6,357-101,287)$ \\
Total & 27 & 45,0 & 33 & 55,0 & 60 & 100 & & \\
\hline
\end{tabular}

Dari hasil analisis pada tabel 3 mengenai hubungan tingkat pengetahuan ibu tentang demam dengan penanganan demam pada 60 responden diperoleh bahwa ibu yang penanganan demam tidak baik dengan pengetahuan kurang baik sebesar 21 (84\%) dan dengan pengetahuan baik sebesar 6 (17,1\%). Sedangkan ibu yang penanganan demam baik dengan pengetahuan kurang baik sebesar $4(16 \%)$ dan dengan pengetahuan baik sebesar 29 (82,9\%). Dapat disimpulkan bahwa ada hubungan tingkat pengetahuan ibu tentang demam dengan penanganan demam dengan Pvalue o,000 (<0.05) dengan odds Ratio

sebesar 25.375 (6.357-101.287) dimana ibu dengan penanganan demam tidak baik akan berisiko sebesar 
25.375 kali memiliki pengetahuan kurang baik.

\section{Pembahasan}

\section{A. Analisis Univariat}

\section{1) Pengetahuan}

Berdasarkan tabel 1 pada penelitian ini didapatkan hasil sebesar $35(58,3 \%)$ ibu dengan pengetahuan baik dan $25(41,7 \%)$ ibu dengan pengetahuan kurang baik. Dapat disimpulkan bahwa sebagian besar pengetahuan ibu tentang penanganan demam adalah baik.

Sejalan dengan teori Notoatmodjo (2010) dimana pengetahuan merupakan hasil dari tahu dan ini terjadi setelah orang melakukan penginderaan yang dimilikinya (mata, hidung, telinga dan sebagainya) terhadap suatu objek tertentu, Pada waktu penginderaan sampai menghasilkan pengetahuan tersebut sangat dipengaruhi oleh intensitas perhatian dan persepsi terhadap objek. Sebagian besar pengetahuan seseorang diperoleh melalui indera pendengaran (telinga), dan indera penglihatan (mata). Pengetahuan seseorang terhadap objek mempunyai intensitas atau tingkat yang berbedabeda.

Pengetahuan seseorang itu dipengaruhi oleh banyak faktor, diantaranya: tingkat pendidikan (pendidikan dapat membawa wawasan atau pengetahuan seseorang. Secara umum seseorang yang berpendidikan lebih tinggi akan mempunyai pengetahuan yang lebih luas dibandingkan dengan seseorang yang tingat pendidikannya lebih rendah), sosial ekonomi (sosial ekonomi dikaitkan dengan pendidikan, jika ekonomi seseorang baik maka pendidikan akan baik juga), lingkungan (lingkungan yang paling berpengaruh besar bagi seseorang adalah keluarga. Dalam lingkungan masyarakat antar warga terjadi transformasi pengetahuan dari satu dengan yang lainnya), informasi (sumber informasi dapat merangsang pengetahuan. Seseorang menerima informasi tersebut akan mempunyai persepsi dan pandangan yang berbeda dengan orang lain, sehingga akan mempengaruhi tingkat pengetahuan. Jadi baik atau buruknya pengetahuan seseorang tergantung kemampuan seseorang dalam perhatian, pemahaman dan penerimaan terhadap info yang diterima), dan pengalaman (dengan pengalaman yang diperolehnya, individu akan memperoleh informasi tentang suatu hal) (Notoatmodjo, 2007).

Sejalan dengan penelitian Lismawati (2014) dengan judul hubungan pengetahuan dan sikap ibu terhadap penanganan demam pada balita Di Wilayah Kerja Puskesmas Payo Selincah Kota Jambi. Dimana pada penelitian ini sebagian besar responden atau sebesar 56,2\% memiliki pengetahuan baik.

Menurut asumsi peneliti ibu dengan pengetahuan kurang baik dikarenakan jarak tempat tinggal jauh dari jangkauan tenaga kesehatan ketika
Ani Kristianingsih, Hubungan Tingkat Pengetahuan...

memberikan sosialisasi kesehatan. Jarak yang jauh membuat warga terutama ibu yang memiliki bayi tidak selalu datang ketika ada informasi kesehatan, serta tenaga kesehatan belum menjangkau rumahrumah yang jauh. Sebaliknya dengan ibu yang memiliki pengetahuan baik dikarenakan jangkauan mereka untuk mendapatkan informasi kesehatan mudah di akses.

\section{2) Penanganan Demam}

Berdasarkan tabel 2 pada penelitian ini didapatkan hasil 33 (55\%) ibu melakukan penanganan demam baik dan 27 (45\%) ibu melakukan penanganan demam tidak baik. Dapat disimpulkan bahwa penanganan demam yang dilakukan ibu sebagian besar adalah baik. Sejalan dengan teori yang menyatakan demam adalah

baiknya temperature tubuh, demam merupakan gejala bukanlah penyakit.

Demam menunjukan adanya infeksi, luka, atau peradangan pada tubuh. Seorang bayi dinyatakan demam bila hasil pengukuran suhu secara oral melebihi $36,7^{\circ} \mathrm{C}$, seorang bayi dinyatakan

demam bila hasil pengukuran suhu melalui ketiak melebihi $37^{\circ} \mathrm{C}$, suhu tubuh yang naik turun merupakan hal yang wajar terjadi pada bayi atau anak sehat. Oleh karena itu peningkatan suhu yang kecil tidak memerlukan perhatian medis, apabila suhu mencapai $38^{\circ} \mathrm{C}$ atau lebih maka perlu mendapat perhatian terutama pada bayi dibawah usia 3 bulan (Dinarti, 2010).

Penanganan demam adalah tindakan yang dilakukan ibu dalam mengatasi demam bayi seperti kompres air hangat, berikan ASI sesering mungkin, menggunakan baju yang menyerap keringat, kondisikan agar ruangan tidak panas. Kemudian secara farmakologi dapat dengan memberikan paracetamol (Handy, 2015). Obat dapat menolong anak menjadi lebih baik tetapi mungkin tidak dapat menghentikan demamnya setiap 4 jam, berikan dosis obat sesuai dengan berat badan anak (Dinarti, 2010).

Sejalan dengan penelitian Ery Khusnul (2012) dengan judul penelitian gambaran prilaku ibu dalam penanganan demam pada anak di Desa Seren Kecamatan Gebang Purworejo. Hasil penelitian ini menunjukan bahwa 62,1\% prilaku ibu dengan prilaku penanganan demam baik.

Menurut asumsi peneliti ibu dengan penanganan demam yang baik dikarenakan sudah memiliki pengalaman sebelumnya tentang penanganan demam anak seperti melakukan kompres, pemberian ASI secara terus-menerus, melakukan pengobtan jika demam tidak kunjung turun. Kemudian didorong dengan informasi dari orang tua dan saudara ibu. Sedangkan penanganan demam yang tidak baik dikarenakan ibu belum memiliki informasi yang banyak tentang penanganan demam. 


\section{B. Analisis Bivariat \\ 1) Hubungan tingkat pengetahuan ibu tentang demam dengan penanganan demam}

Berdasarkan tabel 3 dapat disimpulkan bahwa ada hubungan tingkat pengetahuan ibu tentang demam dengan penanganan demam dengan $\mathrm{P}$-value o,ooo (<0.05) dengan odds Ratio sebesar 25.375 (6.357-101.287) dimana ibu dengan penanganan demam tidak baik akan berisiko sebesar 25.375 kali memiliki pengetahuan kurang baik.

Sejalan dengan teori yang menyatakan penanganan demam adalah tindakan yang dilakukan ibu dalam mengatasi demam bayi seperti kompres air hangat, berikan ASI sesering mungkin, menggunakan baju yang menyerp keringat, kondisikan agar ruangan tidak panas. Kemudian secara farmakologi dapat dengan memberikan paracetamol (Handy, 2015). Obat dapat menolong anak menjadi lebih baik tetapi mungkin tidak dapat menghentikan demamnya setiap 4 jam, berikan dosis obat sesuai dengan berat badan anak (Dinarti, 2010).

Penanganan dilakukan ibu berdasaran dari pengetahuan seseorang. Pengetahuan itu dipengaruhi oleh banyak faktor, diantaranya: tingkat pendidikan (pendidikan dapat membawa wawasan atau pengetahuan seseorang. Secara umum seseorang yang berpendidikan lebih tinggi akan mempunyai pengetahuan yang lebih luas dibandingkan dengan seseorang yang tingat pendidikannya lebih rendah), sosial ekonomi (sosial ekonomi dikaitkan dengan pendidikan, jika ekonomi seseorang baik maka pendidikan akan baik juga), lingkungan (lingkungan yang paling berpengaruh besar bagi seseorang adalah keluarga. Dalam lingkungan masyarakat antar warga terjadi transformasi pengetahuan dari satu dengan yang lainnya), informasi (sumber informasi dapat merangsang pengetahuan. Seseorang menerima informasi tersebut akan mempunyai persepsi dan pandangan yang berbeda dengan orang lain, sehingga akan mempengaruhi tingkat pengetahuan. Jadi baik atau buruknya pengetahuan seseorang tergantung kemampuan seseorang dalam perhatian, pemahaman dan penerimaan terhadap info yang diterima), dan pengalaman (dengan pengalaman yang diperolehnya, individu akan memperoleh informasi tentang suatu hal) (Notoatmodjo, 2007).

Sejalan dengan penelitian Lismawati (2014) dengan judul penelitian hubungan pengetahuan dan sikap ibu terhadap penanganan demam pada balita di Wilayah Kerja Puskesmas Payo Selincah Kota Jambi. Hasil bivariat menunjukan bahwa pengetahuan ibu dengan penanganan demam pada balita $p$-value (o,005) dan sikap ibu dengan penanganan demam pada balita $p$-value $(0,018)$.

Menurut asumsi peneliti dari hasil penelitian sebagian besar pengetahuan ibu kurang baik namun penanganan yang dilakukan sebagian besar baik dikarenakan sumber informasi yang ibu dapatkan kurang tentang penanganan demam secara keseluruhan karena didorong dari akses ibu untuk mendapatkan informasi kesehatan jauh. Namun penaganan yang dilakukan baik karena diperoleh dari pengalaman sebelumnya baik dari keluarga dan saudara ibu, sehingga pada saat bayi demam ibu telah diberi tahu cara untuk melakukan penanganan secepat mungkin. Dan ketika bayi tidak kunjung turun demamnya ibu akan membawa ke fasilitas kesehatan disitu telah diberitahukan juga cara untuk melakukan penanganan demam.

Upaya yang dapat dilakukan untuk meningkatkan pengetahuan ibu tentang penanganan demam yaitu dengan dilakukan sosialisasi oleh bidan, kader, dan tenaga kesehatan lainnya. Diupayakan agar dapat menjangkau tempat pemukiman yang jauh, sehingga para ibu tidak kekurangan informasi.

\section{SIMPULAN DAN SARAN}

\section{Kesimpulan}

a) Distribusi frekuensi pengetahuan ibu di Desa Datarajan Wilayah Kerja Puskesmas Ngarip Kabupaten Tanggamus, 35 (58,3\%) ibu dengan pengetahuan baik dan $25(41,7 \%)$ ibu dengan pengetahuan kurang baik.

b) Distribusi frekuensi penanganan demam pada bayi o-12 bulan di Desa Datarajan Wilayah Kerja Puskesmas Ngarip Kabupaten Tanggamus, 33 (55\%) ibu melakukan penanganan demam baik dan 27 (45\%) ibu melakukan penanganan demam tidak baik

c) Ada hubungan tingkat pengetahuan ibu tentang demam dengan penanganan demam dengan Pvalue o,ooo (<0.05) dengan odds Ratio sebesar 25.375 (101.287-6.357).

\section{Saran}

a) Bagi Responden

Diharapkan hasil penelitian ini dapat menambah pengetahuan bagi ibu dengan pengetahuan kurang baik. Ibu dapat mengikuti sosialisasi kesehatan. Kemudian ibu dapat melakukan penanganan demam yang baik didorong dengan adanya informasi kesehatan baik dari tenaga kesehatan ataupun orang tua dan saudara ibu dalam penanganan demam.

b) Bagi Posyandu

Diharapkan hasil penelitian ini dapat meningkatkan pelayanan kesehatan dalam pendidikan kesehatan pada ibu tentang penanganan demam pada bayi. Meningkatkan pengetahuan ibu tentang penanganan demam yaitu dengan dilakukan 
sosialisasi oleh bidan, kader, dan tenaga kesehatan lainnya. Diupayakan agar dapat menjangkau tempat pemukiman yang jauh, sehingga para ibu tidak kekurangan informasi.

c) Bagi STIKES Aisyiyah Priwengu

Diharapkan hasil penelitian ini dapat digunakan sebagai tambahan ilmu pengetahuan sehingga dapat menambah wawasan dan informasi bagi mahasiswa mahasiswi STIKes Aisyah Pringsewu. Serta menjadi sumber kepustakaan di STIKes Aisyah Pringsewu.

d) Bagi Peneliti Selanjutnya

Diharapkan hasil penelitian ini bahan kajian lebih lanjut bagi peneliti selanjutnya mengenai hal yang sama secara lebih mendalam dan dapat menambah jumlah responden, serta mengunakan metodelogi penelitian yang berbeda.

\section{UCAPAN TERIMA KASIH}

Tim penulis mengucapkan terimakasih kepada STIKes Aisyah Pringsewu yang telah mensupport dana pada penelitian ini.

\section{DAFTAR RUJUKAN}

[1] Adiningsih, 2010. Waspadai Gizi Bayi dan Balita Anda. Jakarta; PT Alex Media Komputindo

[2] Arikunto, S. 2013. Prosedur Penelitian. Jakarta; Renika Cipta

[3] Dinarti, 2010. Baby And Child Health Dari Lahir Hingga 5 Tahun. Jakarta; G-Media

[4] Diniyanti, 2011. Penangganan Demam Pada Anak. Elmeida, 2015. Asuhan Kebidanan Neontus bayi dan Balita. Jakarta; CV Trans Info Media

[5] Ery Khusnul (2012) dengan judul penelitian gambaran prilaku ibu dalam penanganan demam pada anak di Desa Seren Kecamatan Gebang Purworejo.

[6] NursingJurnal.respatiac.id/index.php/JKTM/article/vie w/11. Diakses pada tanggal 22 Mei 2018

[7] Widagdo, 2012. Masalah Dan Tatalaksana Penyakit Anak Dengan Demam. Jakarta; Sagung Seto..

[8] Fauzie, Rifan, 2014. Pengaruh Kejang Demam Terhadap Kecerdasan Anak. http://health.compas.com/read/2011/12/1306049 1/pengaruh.kejang.demam.pada.kecerdasan. Diakses pada tanggal 19 Oktober 2017

[9] Handy, 2015. A-Z Perawatan Bayi. Jakarta; Pustaka Bunda, Group Puspa Swara

[10] Harianti, 2016. Hubungan Tingkat Pengetahuan Ibu Tentang Demam Dengan Prilaku Ibu Dalam Penanganan Demam Pada Anak Balita Di Puskesmas Depok Sleman Yokyakarta.

NursingJurnal.respatiac.id/index.php/JKRY/arti cle/view/26. Diakses pada tanggal 20 Oktober 2017

[11] Kania, 2010. Penatalaksanaan Demam Pada Anak. http://hiperkes.com/pdf/nia-kania- penatalaksanaandemam.html. diakses pada tanggal 20 Oktober 2017

[12] Lismawati, 2014. Hubungan Pengetahuan Dan Sikap Ibu Tentang Demam Pada balita Di Wilayah Kerja Puskesmas Kota Jambi. Ojs.stikesprimajambi.ac.id/index.php/sc/article/view/31. Diakses pada tanggal 20 Oktober 2017
Ani Kristianingsih, Hubungan Tingkat Pengetahuan...

[13] Lisnawati, 2013. Asuhan Kebidanan Kegawat Daruratan Maternal Neonatal. Jakarta; CV. Trans Info Media

[14] Notoatmodjo, 2010. Prilaku Kesehatan Dan Ilmu Prilaku. Jakarta; Renika Cipta

[15] Notoatmodjo, 2010. Metodologi Penelitian Kesehatan. Jakarta; Renika Cipta

[16] Nursalam, 2008. Konsep \& Penerapan Metodelogi Penelitian Ilmu Keperawatan. Jakarta; Salemba Medika

[17] Nursalam, 2007. Ilmu Kesehatan Anak. Jakarta; Salemba Medika

[18] Potter \& Perry, 2008. Fundamental Of Nursing. Jakarta; EGC

[19] Rukiyah, 2013. Asuhan Neonatus Bayi Dan Anak Balita. Jakarta; CV Trans Info Media

[20] Susanti, 2009. Gangguan Bicara Dan Bahasa Pada Anak.http://www.dokteranakku.com/wp,content/downl oads/buku\%20gangguan\%2obicara\%20bahasa. pdf. Diakses pada tanggal 19 Oktober 2017

[21] Setyani, 2014. Gambaran Prilaku Ibu Dalam Penanganan Demam Pada Anak Di Desa Seren Kecamatan Purworejo. Digilib.unisayogya.ac.id/549/. Diakses pada 19 Oktober 2017

[22] Suryaningsih, 2013. Penanganan Demam Pada Bayi Balita. $\quad$ http://penanganan-demam-pada-bayibalita.htm. Diakses pada 19 Oktober 2017 